Hydrol. Earth Syst. Sci. Discuss., 5, 1731-1763, 2008 www.hydrol-earth-syst-sci-discuss.net/5/1731/2008/

(C) Author(s) 2008. This work is distributed under the Creative Commons Attribution 3.0 License.
Hydrology and Earth System Sciences Discussions

Papers published in Hydrology and Earth System Sciences Discussions are under open-access review for the journal Hydrology and Earth System Sciences

\title{
Road and stream network connectivity and potential: northeastern Puerto Rico, an exploratory analysis
}

K. R. Sherrill ${ }^{1}$, M. J. Laituri ${ }^{1}$, E. H. Helmer ${ }^{2}$, J. A. Ramirez ${ }^{3}$, J. F. Blanco ${ }^{4}$, K. Hein ${ }^{5}$, and A. S. Pike ${ }^{6}$

${ }^{1}$ Department of Forest Rangeland and Watershed Stewardship, Colorado State University, Fort Collins, CO 80523-1472, USA

${ }^{2}$ International Institute of Tropical Forestry, USDA Forest Service, Fort Collins, CO 80526-2098, USA

${ }^{3}$ Dept. of Civil Engineering, Colorado State University, Fort Collins, CO 80523-1472, USA

${ }^{4}$ Instituto de Biologia, Unversidad de antoquia, Medllin, Colombia

${ }^{5}$ Department of Aquatic, Watershed and Earth Resources, Utah State University, Logan, UT 84322-5210, USA

${ }^{6}$ Department of Earth and Environmental Science, University of Pennsylvania, 254-b Hayden Hall, 240 South 33rd Street Philadelphia, PA 19104-6316, USA

HESSD

$5,1731-1763,2008$

Road and stream network connectivity and potentail

K. R. Sherrill et al.

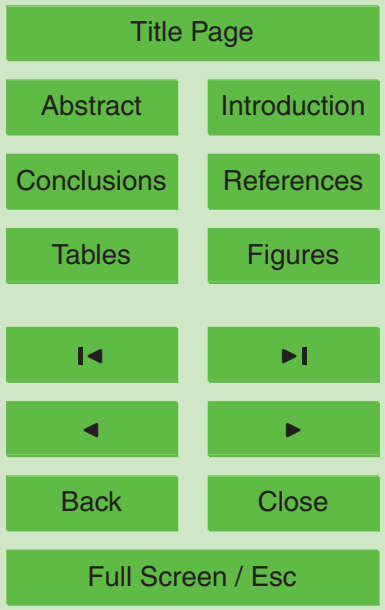

Printer-friendly Version

Interactive Discussion 
Received: 4 June 2008 - Accepted: 15 June 2008 - Published: 9 July 2008

Correspondence to: K. R. Sherrill (sherrill @cnr.colostate.edu)

HESSD

Published by Copernicus Publications on behalf of the European Geosciences Union.

$5,1731-1763,2008$

\section{Road and stream network connectivity and potentail \\ K. R. Sherrill et al.}

Title Page

Abstract Introduction

Conclusions References

Tables

Figures

14

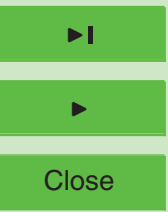

Back

Full Screen / Esc

Printer-friendly Version

Interactive Discussion 


\section{Abstract}

Interactions between road and stream networks are complex and are influenced by a range of environmental and road design characteristics. These interactions are not clearly understood and are the subjects of current research. To increase understanding 5 of these interactions we explore the concepts of Road and Stream Network Connectivity (R/S Connectivity) and Road and Stream Network Connectivity Potential (RSNCP). Lastly we provide a methodology for study and analysis of R/S connectivity.

This study focuses on road induced alterations to sediment and water flow processes, which are important road effects of R/S connectivity. For 25 river road cross-

ings (RRC) in the Rio Mameyes and Rio Espiritu watersheds of Northeastern Puerto Rico, a multi-scale Geographic Information Systems (GIS) database measuring environmental and road characteristic variables was developed specifically to measure variables influencing sediment and water flow. Multivariate analysis methods were used to select the environmental and road characteristic variables which were used in 5 multiple linear regression models for three biota variables (Decapod Richness, Adult Fish Richness, and Total Richness), and four stream habitat geomorphology variables (Median Channel Grain Size, Active Channel Maximum Depth, Pool Volume, and Active Channel Width). Explained variance $\left(R^{2}\right)$ from modeling results ranged from 0.22 to 0.86 , demonstrating that the GIS derived variables can successfully be used to model important stream biota and geomorphology response variables.

\section{Introduction}

Roads have a pervasive effect on the environment, and finding a terrestrial ecosystem that is not to some degree influenced by roads and automobiles would be difficult. Many adverse effects can be attributed to roads, such as increased pollution (Forman and Alexander, 1998; Cornish, 2001; and Forman et al., 2003), alteration of physical habitat including effects of fragmentation (population isolation, road avoidance) (Reed
HESSD

5, 1731-1763, 2008

\section{Road and stream network connectivity and potentail}

K. R. Sherrill et al.

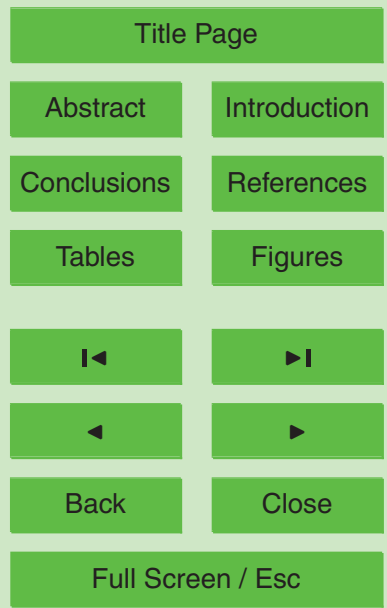

Printer-friendly Version

Interactive Discussion 
et al., 1996); noxious species spread; and effects resulting from altered water and sedimentation processes. Forman (2000) estimated that $19 \%$ of the total area of the United States is ecologically affected by roads and vehicle traffic. The area over which significant ecological effects extend has been termed the "road-effect zone" (Forman 5 and Alexander, 1998). "Road effect zones" vary in size but usually extend beyond the physical road width (Forman and Alexander, 1998; Forman, 2000). Although people are aware of the adverse effects from roads and vehicles, little scientific evidence exists that quantifies the cumulative effects of roads on the environment (Forman 2003, et al.).

This study explores the concept of road/stream network connectivity (R/S connectiv10 ity), which is a broad term referring to the intensity of connections between roads and streams. That intensity, the R/S connectivity, determines energy and mass transfers between stream networks and roads. R/S connectivity governs the degree to which roads affect stream ecosystem processes such as sedimentation, water flow, nutrient cycling, stream chemistry, aquatic species movement and mortality to name a few. R/S connectivity effects on streams occur through many direct and indirect interactions between roads, watersheds, and streams. With regards to sediment and water flow R/S connectivity, increased R/S connectivity results in increased alteration of sediment and water flow processes and conversely, decreased R/S connectivity has reduced alteration of sediment and water flow processes. Because R/S connectivity interactions are complex, our knowledge of which variables can cumulatively gauge them is poor.

Most of the negative effects of roads on streams occur via unintended alteration of hydrologic and sediment flow (Montgomery, 1994; Walker et al., 1996; Jones and Grant, 1996; Wemple et al., 1996, 2001; Forman and Alexander, 1998; Lugo and Gucinski, 2000; Layman et al., 2004; Croke et al., 2005; and Ramos-Scharron and MacDonald, 2005). Roads influence water and sediment processes across landscapes by acting as sources for increased runoff, via movement along ditches, and road surfaces, and by intercepting subsurface water flows. Culverts can act as physical barriers to aquatic species movement. These physical barriers are usually in the form of vertical barriers, water velocity barriers and from altered sediment flow (Montegomery, 1994;

\section{HESSD}

$5,1731-1763,2008$

\section{Road and stream network connectivity and potentail}

K. R. Sherrill et al.

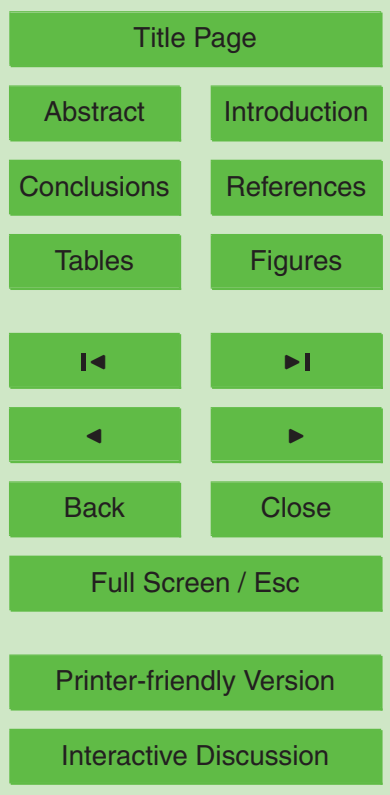

Interactive Discussion 
Forman, 1995, 2003; Warren and Pardew, 1998; Wemple et al., 2001; Layman et al., 2004; Gibson et al., 2005).

The underlying hypothesis for this paper is that multi-scale explanatory variables derived with GIS can predict important field derived stream biota and geomorphology 5 responses that are influenced by R/S Connectivity. This study focuses on environmental and road characteristic variables that influence the amount by which roads alter sedimentation and water flow processes.

The objectives of this study are as follows: 1) Discuss and illustrate the concepts of $\mathrm{R} / \mathrm{S}$ connectivity, 2) Use variable reduction techniques to focus on sets of uncorre10 lated variables that may best gauge $\mathrm{R} / \mathrm{S}$ connectivity related to sediment and water processes in the study landscape, 3) Determine if these derived variables can explain significant variance in stream habitat and species richness response variables. These response variables are indicators of ecosystem health that $R / S$ connectivity may affect. For example, if a road alters stream sediment and water flow, it may reduce the overall 15 health of the stream ecosystem. GIS derived environmental variables were selected to measure inherent differences in the environmental setting and their erosion potential. Road characteristic variables specifically are measuring the potential for road perturbation occurrence within the environment.

\subsection{Road and stream network connectivity (R/S Connectivity)}

20 Two major categories of R/S connectivity include those: 1) from direct physical contact, usually occurring at river road crossings, between the road and stream network which we refer to as direct $R / S$ connectivity and 2) from less direct pathways in which alteration of stream or watershed processes occur due to roads being within a vicinity of the stream network, but not directly in contact. Direct R/S connectivity is strongly influenced by the crossing type (bridge or culvert) and the placement of the structure within the stream. Crossing structures sometimes act as barriers altering stream biota movement or water and sediment flow. R/S connectivity from roads being within the vicinity of stream networks is largely a function of: 1) Road location or road proximity to

HESSD

5, 1731-1763, 2008

\section{Road and stream network connectivity and potentail}

K. R. Sherrill et al.

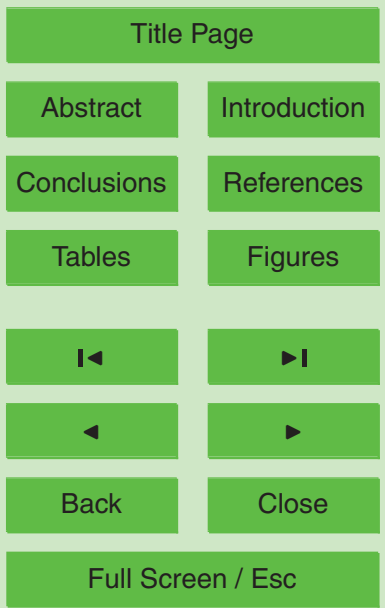

Printer-friendly Version

Interactive Discussion 
the stream network and 2) the intervening environmental variables between the road and stream network.

We define Road and Stream network connectivity potential (RSNCP) as the naturally occurring potential for R/S connectivity that a given watershed or engineering 5 design has before a road is built. The erosion potential of the environment, gives it an inherent potential for R/S connectivity. For example an environment without a road has erosion potential but no R/S connectivity. Streams in erosion-prone environments relative to streams in erosion resistant environments are likely more susceptible to the disturbances of roads and will have increased RSNCP.

10 RSNCP for road crossing structures is largely controlled by engineering design. An engineering design that places roads closer to streams has greater RSNCP based simply on proximity (Fig. 1a); however the overall amount of R/S connectivity also depends on the intervening environmental variables. Conversely, if the same road segment is farther from the stream network, RSNCP is reduced (Fig. 1b). The potential transfers

the road and stream network also influences the potential for road effects from R/S connectivity. These potential transfers are influenced by environmental characteristics such as land cover type, underlying geology, slope level, and annual precipitation.

A situation that would be considered to have reduced RSNCP is shown in Fig. 1C. 20 The road is distant from the stream network and is located in a natural setting that is resistant to R/S connectivity because the road is on gently sloping terrain, with a densely forested riparian buffer between the road and stream network. Conversely, a situation where the environmental conditions are more conducive for R/S connectivity is shown in Fig. 1d. The same road is distant from the stream network but is located on highly sloped terrain with a sparsely vegetated riparian buffer between the road and stream network.

While this study focuses on R/S connectivity resulting in alteration of sediment and water processes, it is important to emphasize that R/S connectivity is not limited to alteration of these processes. For example roads in an environment can yield increased

HESSD

5, 1731-1763, 2008

\section{Road and stream network connectivity and potentail}

K. R. Sherrill et al.

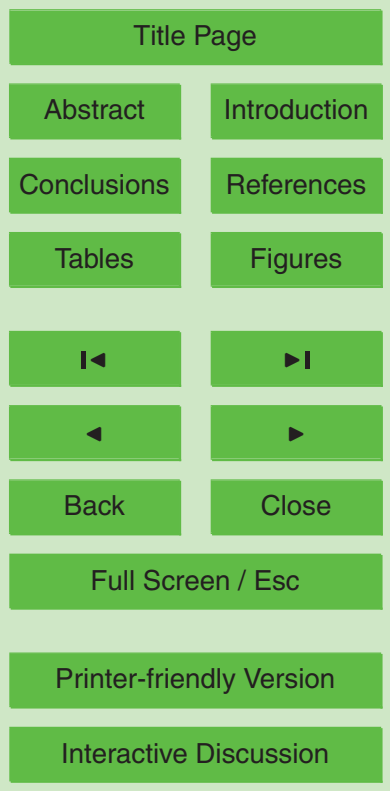

Interactive Discussion 
human access to the stream network, which in turn creates numerous pathways of $\mathrm{R} / \mathrm{S}$ connectivity. This increased human access can yield greater harvesting of aquatic species (fish, shrimp, crabs, etc.), thus representing R/S connectivity related to harvest mortality. Likewise increased access to the stream network may facilitate increased 5 recreational activities such as picnicking and swimming near and within the stream. Increased picnicking may yield greater garbage deposition in the stream, while recreational swimming can effect stream turbidity and result in biota avoidance, each representing unique sources of $\mathrm{R} / \mathrm{S}$ connectivity respectively. These examples are only provided for illustrative purposes to stress that the cumulative R/S connectivity within a 10 system is a function of interactions between numerous elements and processes which are affected by R/S connectivity.

\subsection{Study area and sites}

Analyses were performed in the Rio Espiritu Santo and the Rio Mameyes watersheds in the Luquillo Mountains of Northeastern Puerto Rico (NE PR) (Fig. 2). NE PR has 15 an altitudinal gradient from sea level at the Atlantic Ocean to over $1000 \mathrm{~m}$ at the summits of the Luquillo Mountains. Slopes closely follow this gradient with gentle slopes $(<5.0 \%)$ along the coastal plain to steep slopes $(>45.0 \%)$ in mountainous terrain at higher elevations.

There is a continuum of four main forest vegetation types that are influenced by 20 topographically controlled climatic and soil conditions (Foster et al., 1999; and Lugo and Scatena, 1995). Above 300-400 m elevation and below elevations of $610 \mathrm{~m}$ are Tabonuco dominated forests (Lugo and Scatena, 1995). Above $610 \mathrm{~m}$, on gently sloping and saturated soils, is the Palo Colorado forest type. The Sierra Palm forest is found intermixed within the Tabonuco and Palo Colorado forest above an elevation of $25550 \mathrm{~m}$ on steep slopes and streambeds. Stunted Dwarf forest vegetation is found on the nutrient poor, high elevation ridge tops (Lugo and Scatena, 1995; Weaver, 1995).

Lower elevations (less than $50 \mathrm{~m}$ ) outside of the Caribbean National Forest (CNF) boundary are dominated by urban and pasture/agriculture land cover types and dry

\section{HESSD}

$5,1731-1763,2008$

\section{Road and stream network connectivity and potentail}

K. R. Sherrill et al.

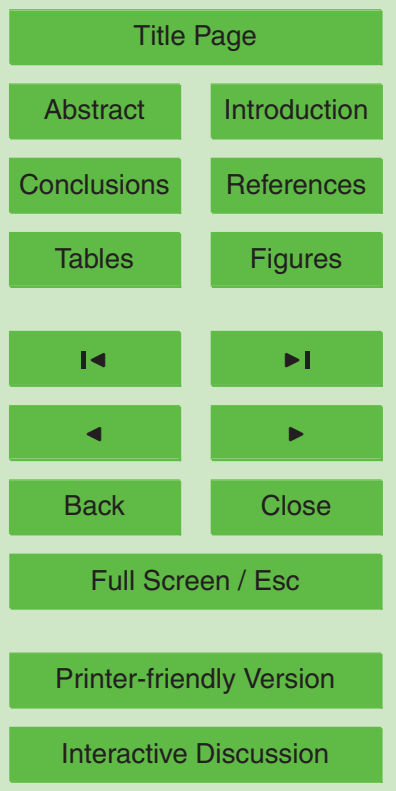


and moist forest types (Helmer, 2004). The study area is dominated geologically by extrusive volocaniclasitic rock in the northern Luquillo Mountains (Walker et al., 1996), and by a mixture of extrusive, alluvial, and intrusive geologies on the coastal plain.

Since the late 1940's, Puerto Rico has changed from an agrarian to a predominately 5 industry-driven economy. This socio-economic change has yielded a population shift from rural to urban areas, resulting in conversion of agricultural lands to secondary forest cover (Foster et al., 1999; Lugo, 2002; Thomlinson and Rivera, 2000; Grau et al., 2003; Helmer, 2004). This conversion of agriculture to forested land cover has been termed "spontaneous reforestation" (Rudel et al., 2000).

The 25 study sites in this analysis were selected using a hierarchical road and stream size matrix. Sample sites were selected to represent all combinations of stream (1-4 order Strahler) and road sizes (primary: large 4 lane highway, secondary: 2 lane road, tertiary: 1 lane road, class 4: 1 lane dirt road and, trails) (Table 1).

\subsection{Scale}

15 Hierarchy theory in ecology suggests that studying patterns of processes at multiple scales is necessary because processes are scale dependent (Forman, 1995; Turner et al., 2001). To facilitate recognition of landscape patterns that influence R/S connectivity, a hierarchical road characteristics and environmental variables GIS database was developed. This analysis used four scales of study: (1) a local Buffer (Buf) scale defined 20 as a $250 \mathrm{~m}$ circular radius around each study site, (2) a stream buffer (Stb) scale defined as a $200 \mathrm{~m}$ upstream stream buffer above each study site, (3) an upstream (Ups) contributing area catchment scale and (4) a combined scale (All), which is a combination of all scales (Buf, Stb, and Ups) (Fig. 3). Upstream catchments were calculated with ArcGIS 9.1 and Arclnfo hydrological analysis tools including flow direction, fill sink, 25 flow accumulation and watershed functions (ESRI). The Buf scale circular buffers and Stb scale stream buffers were calculated with ArcGIS 9.1 ArcToolbox proximity buffer tools (ESRI).

\section{HESSD}

$5,1731-1763,2008$

\section{Road and stream network connectivity and potentail}

K. R. Sherrill et al.

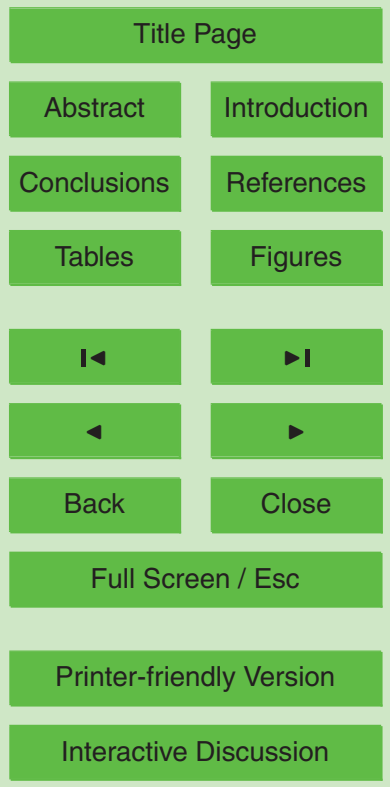




\section{Methods}

This study explores the concepts of R/S connectivity and RSNCP by developing and interpreting models of stream habitat and stream biota richness variables using environmental and road characteristic explanatory variables. The following is a brief outline of 5 steps performed in this analysis: 1) A road and environmental variables GIS database was developed. 2) Multivariate variable reduction analysis was performed using correlation analysis, Variance Inflation Factors (VIF) (Neter et al., 1996), and Principal Component Analysis (PCA) to identify the GIS variables used in regression modeling per response variable. 3) Modeled response variables were, biota richness variables:

10 Decapod Richness, Adult Fish Richness and Total Richness, and four stream habitat geomorphology response variables: Median Active Channel Grain Size, Active Channel Maximum Depth, Pool Volume, and Active Channel Width. 4) The models were interpreted to gain better understanding of R/S connectivity in the study area.

\subsection{Environmental variables}

15 Environmental variables such as the intervening vegetation and land cover types (Larsen and Torress-Sanchez, 1995; Roth et al., 1996; Forman et al., 2003), slope levels (Larsen and Torress-Sanchez, 1995; Walker et al., 1996; Jones et al., 2000; Lugo and Gucinski, 2000; Wemple et al., 2001), underlying geology (Guariguata, 1990; Larson and Torres-Sanchez, 1995; Lugo and Gucinski, 2000; Wemple et al., 2001) ri20 parian vegetation cover type (Roth et al., 1996; Gergel et al., 2002), riparian cover connectivity, and width of riparian vegetation (Weller et al., 1998; Heartsill-Scalley and Aide, 2003) all can affect R/S connectivity.

Derived environmental variables at the three scales of study include: proportion land cover forest, agriculture, and urban, proportion underlying geology extrusive, intrusive tion, average precipitation, aspect proportions, average riparian vegetation (100 m per stream side buffer) patch size by land cover type (forest, agriculture, urban), and pro-

\section{HESSD}

$5,1731-1763,2008$

\section{Road and stream network connectivity and potentail}

K. R. Sherrill et al.

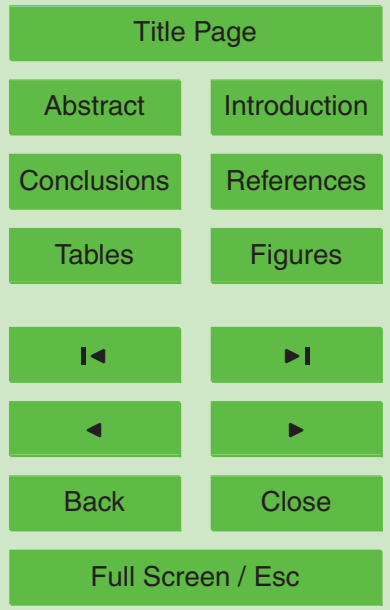

Printer-friendly Version

Interactive Discussion 
portion vegetation along the stream buffer that is forest, agriculture and urban (Table 2). (Proportion values where calculated as the amount of variable $X$ (i.e. forest landcover, or extrusive geology) relative to the total area in the scale of study). The expected relationships (positive or negative) of the environmental variables with increased and 5 decreased R/S connectivity are shown in Table 3.

Environmental variables were derived using a $10 \mathrm{~m}$ Digital Elevation Model (DEM) for elevation, slope, aspect, and hillslope calculations; a 1995 land cover layer (Ramos Gonzalez 2001); an underlying geology layer (USDA); and an ownership layer. Other environmental variables not measured, such as soil texture, soil infiltration properties, 10 bulk density, percent vegetative cover, Leaf Area Index, forest age and, structure, etc., would also be expected to strongly influence RSNCP related to sediment and water processes.

\subsection{Road characteristics}

At all scales of study (Buf, Stb, and Ups), four road characteristics were measured. 15 These included the number of river road crossings (RRC), road length in a $200 \mathrm{~m}$ river buffer (measured on each side of river), road density by road class, and road density by hillslope location (ridge, flat, or valley) (Table 4). The expected relationships (positive or negative) of the road characteristic variables with increased and decreased R/S connectivity are shown in Table 3. Derivation of hillslope position was done in ArcView 203.3 using the script knf.LandFormlndexGrid script (Thomas and Joy, 1998) on a $10 \mathrm{~m}$ DEM. From the derived Landform Index Grid, road density within each of three categories of slope position, concavity (valleys), convexity (ridges) and flat (minimal slope) were evaluated. Road characteristic variables were derived using GIS analysis on the Landform Index layer, USGS Digital Line Graph road network, and stream network 25 layers obtained originally from the Luquillo Experimental Forest GIS database.

In NE Puerto Rico landslide frequency was found to be five times more frequent in area less than $85 \mathrm{~m}$ from a highway related to areas greater than 85 meters (Larsen and Parks, 1997). Measuring the number of RRC at each scale incorporates measure-

HESSD

5, 1731-1763, 2008

\section{Road and stream network connectivity and potentail}

K. R. Sherrill et al.

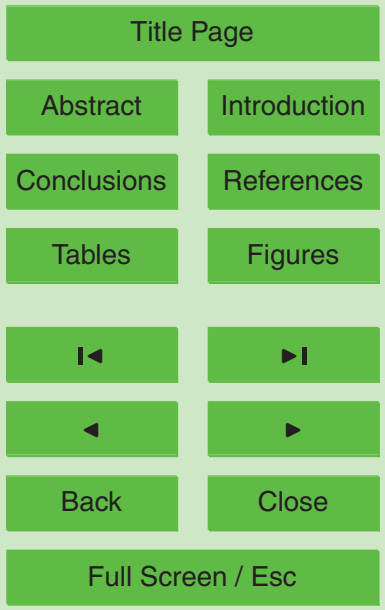

Printer-friendly Version

Interactive Discussion 
ment of R/S connectivity from increased sediment input occurring at crossings (Cornish, 2001; Croke et al., 2005). Road location (Lugo and Gucinski, 2000; Wemple et al., 2001; Croke et al., 2005) and road hillslope position (Furniss et al., 1991; Jones et al., 2000) may influence R/S connectivity. Measures of road Density by road size were 5 calculated. Road size is a surrogate measure of road use, with larger roads expected to have greater vehicle usage. Road usage, as measured by daily vehicle numbers, can influence road effects upon the environment (Clark and Karr, 1979; Reijnen and Foppen, 1994; Reijnen et al., 1995; Reijnen et al., 1996; Wasser et al., 1997; Lugo and Gucinski, 2000; Mumme et al., 2000; Forman et al., 2002; Croke et al., 2005). 10 Larger road classes may have greater R/S connectivity relative to smaller sized roads with less traffic.

\subsection{Variable reduction}

For each scale of study a variable reduction process was performed using a correlation matrix, VIF calculations, and PCA. Variability within multivariate ecological data is often explained by a few variables that are related to certain ecological or environmental variables (McGarigal et al., 2000). Multivariate analysis tools such as PCA can be utilized to identify the variable(s) most important to community organization. (Isebrands and Crow, 1975; Nichols, 1977).

Using a correlation matrix, variables were removed until all variables had correla-

tions less than 0.80 . Calculation of VIF was done in an iterative manner with single variable removal until all VIF values were less than 10 (Kellum, 2002). Finally, using criteria from Isebrands and Crow (1975) and Jeffers (1967), all eigenvalues (components) greater than 1.0 or the next eigenvalue less than 1.0 were considered significant and retained. Selection of the key eigenvectors (loadings) within each significant 25

\section{HESSD}

$5,1731-1763,2008$

\section{Road and stream network connectivity and potentail}

K. R. Sherrill et al.

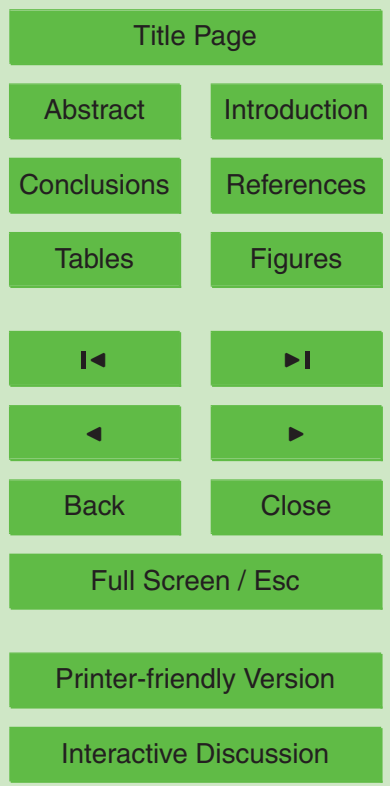




\subsection{Modeling response variables}

Stream biota and stream habitat geomorphology variables were used as response variables. These data were collected by researchers working on the Biocomplexity Grant \# DEB-0308414. Geomorphology variables included active channel maximum depth 5 (Channel Depth), active channel width (Channel Width), pool volume (Pool Volume), and a log transformed median grain size (Grain Size) in the active channel (Active channel was defined as the channel that is inundated with flow $1 \%$ of the time). For the geomorphology data only the pool which was closest to the river road crossing or the nearby pool which experiences high human recreation were included in analysis. Biota data included species richness (number of species present) for decapod (shrimp and $\mathrm{crab}$ ) and for fish (fish and eel). Using the Decapod and Fish Richness data, a third biota measure, Total Richness (shrimp and decapod richness combined) was derived.

Best model selection for each response variable was determined using Efroymson Stepwise Regression and a Leaps and Bounds selection procedure (Furnival, 1974). 15 The models with the highest explained variance $\left(R^{2}\right)$ and lowest Akaike's Information Criterion (AIC) were selected as most fit. A second set of models was developed under the same process but including study site spatial coordinates $X$ \& $Y$ (Latitude and Longitude) as potential explanatory variables.

Variables directly influenced by road and stream network interactions (R/S connectivity) related to sediment and stream flow processes would include: channel and hillslope erosion rates, and water flow characteristics such as peak flow timing and volume. These directly related variables ideally would have been used in an exploratory modeling analysis of R/S connectivity. This data, however, was not available, which forced the use of the aforementioned biota and geomorphology response variables which, relative to erosion and water flow variables, are more indirectly influenced by R/S connectivity.

HESSD

$5,1731-1763,2008$

\section{Road and stream network connectivity and potentail}

K. R. Sherrill et al.

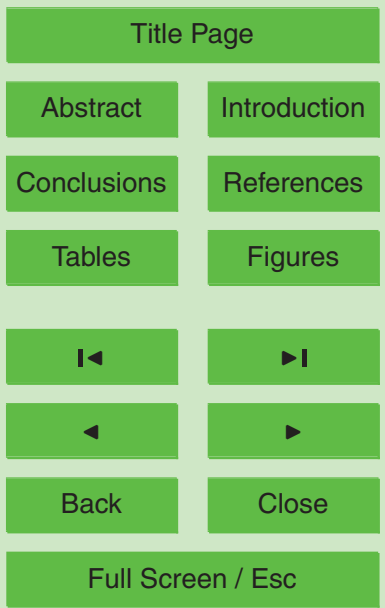

Printer-friendly Version

Interactive Discussion 


\section{Results and discussion}

\subsection{Modeling}

HESSD

The significant environmental and road characteristic variables retained after the variable reduction process and used in the regression modeling are shown in Table 5. For 5 each response variable, only the scale of study with the most explained variance $\left(R^{2}\right)$ and lowest AIC is shown. Stream biota response models have $R^{2}$ values ranging from 0.51 to 0.74 (Table 6), while Geomorphology models having $R^{2}$ values ranging from 0.22 to 0.86 (Table 7). Overall thirteen of the fourteen best models across all scales were models using variables measured at the combined scale (All). Influences on response variables are occurring at multiple scales from the localized 250 meter circular buffer (Buf) scale to the broadest upstream contributing area (Ups) scale, suggesting that RSNCP is influenced by processes and patterns occurring at multiple scales.

\subsection{Response variables}

In this discussion we emphasize the observed relations (positive or negative) within models between the dependent biota and geomorphology response variables (coefficients) and the independent road and environmental variables. Because these independent variables have known relationships with water and erosion processes, we use the observed relationships to explore potential implications with the concept of R/S connectivity.

Biota richness variables are expected to be negatively related with $\mathrm{R} / \mathrm{S}$ connectivity. If so, increased potential for R/S connectivity, RSNCP, should be related to decreased species richness due to alteration and degradation of habitat when roads are present. It is necessary to emphasize this is a hypothesized response, as not all human induced changes are environmentally damaging, and care should be taken to avoid prejudging all human change as degrading (Lugo and Gucinski, 2000).

The geomorphology variables are proxies of stream biota habitat. Pool volume on

\section{Road and stream network connectivity and potentail}

K. R. Sherrill et al.

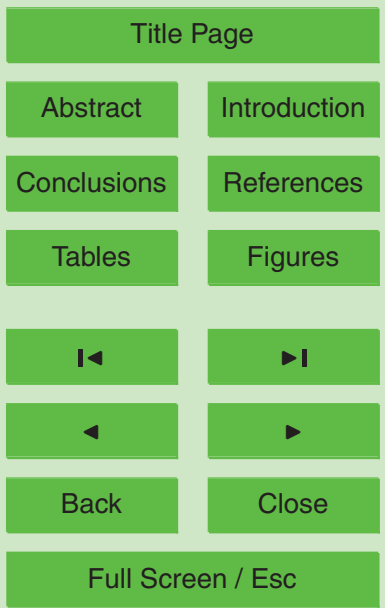

Printer-friendly Version

Interactive Discussion 
head water streams and water depth on second and third order streams of the Luquillo Experimental Forest (LEF), are strong predictors of shrimp abundances (Scatena and Johnson, 2001). A priori responses of Pool Volume, Channel Depth, and Channel Width to R/S connectivity are difficult to generalize. Sites having greater R/S connec5 tivity might have smaller pool volumes and decreased maximum channel depths due to greater erosion and sediment deposition. At the same time, sites having more erosion might have wider stream channels due to increased channel bank erosion. Higher peak stream flow, which is a product of increased R/S connectivity, could also increase channel scour, yielding deeper stream channels.

10 Expected Grain Size response to increased R/S connectivity would be decreased grain size due to increased accumulation of small sized sediment from increased erosion. Stream beds with larger grain sizes are more resistant to erosion than stream beds having smaller grain sizes (Allan, 1995). Sites with larger median grain size should be more resistant to erosion occurring from R/S connectivity.

\section{$15 \quad 3.3 \quad$ Biota models}

The Decapod Richness models have positive coefficients with Extrusive geology (Ext.Stb) and Riparian vegetation forest patch size (RipForPatch). Landslide studies in the LEF have found that extrusive geology types are more resistant to landslide slippage and erosion from weathering (Guariguata, 1990) and have lower sediment yield ity to act as a buffer to sediment and water flow is determined largely by the connectivity (continuity) of the riparian vegetation (Heartsill-Scalley and Aide, 2003). The Riparian vegetation forest patch size (RipForPatch) variable measures the connectivity of the riparian vegetation, thus increased RipForPatch values (average patch size divided by riparian area, values ranging between 0 and 1 , with 1 being one continuous patch) should decrease R/S connectivity potential (RSNCP). These positive coefficients with Extrusive geology and Riparian vegetation imply higher richness is associated with more stable extrusive geology, and larger continuous forest patches along a $100 \mathrm{~m}$

HESSD

$5,1731-1763,2008$

\section{Road and stream network connectivity and potentail}

K. R. Sherrill et al.

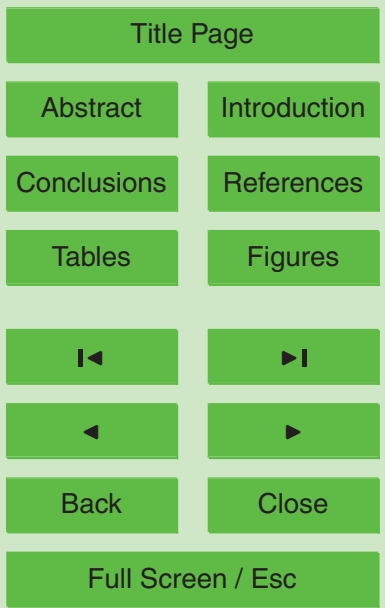

Printer-friendly Version

Interactive Discussion 
upstream buffer.

The Fish Richness model with $X$ and $Y$ is negatively related with erosive Intrusive geology (Int.Buf), and positively related with Agricultural land cover (Agri.Buf) and Y. In this study area, most fish species distributions are limited to elevations occurring be5 low naturally occurring vertical barriers on the stream network (Covich and McDowell, 1996). These natural barriers occur on steeper slopes in mountainous terrain that are predominately forested and also in the southern-end (decreasing $\mathrm{Y}$ ) of our study area. Most agricultural land occurs on the less sloped coastal plain in the northern half of the study area, and below the first stream network fish barriers, potentially explaining the 10 positive relations with Agriculture land cover and $\mathrm{Y}$.

Both total richness models without $X \& Y$ and with $X \& Y$ each have 2 underlying geology explanatory variables, length of road in a river buffer (RdBufRiv.Buf), and the public ownership variable (Public.Stb). In the Total Richness model the positive coefficient for extrusive geology (Ext.Stb) and negative coefficient for intrusive geology 15 (Int.Buf) illustrate that R/S connectivity is reduced for extrusive geologies relative to intrusive geologies. These geology relationships may indicate that in the CNF watersheds with more extrusive geology have decreased sedimentation potential and less RSNCP.

Length of road in river buffer (RdBufRiv.Buf) is negatively related to Total Richness.

20 This can be interpreted as increased R/S connectivity as measured by greater road length within a stream buffer being negatively related to Total Richness. Proportion of public ownership is negatively related to total richness in models without and with $X$ \& Y. Approximately $100 \%$ of public land in this study area is located on Caribbean National Forest land. Public ownership in NE Puerto Rico and at the Stream buffer scale

25 (Public.Stb) is highly correlated with forested land cover at the Stream buffer and Upstream scales (Helmer, 2004 and correlation analysis For.Stb 0.90 and For.Ups 0.93), thus public ownership is equivalent to forest land cover. Increased forested land cover relative to agriculture and urban cover types is expected to have decreased RSNCP because of this land cover's ability to reduce water flow velocity and increase soil sta-

HESSD

$5,1731-1763,2008$

\section{Road and stream network connectivity and potentail}

K. R. Sherrill et al.

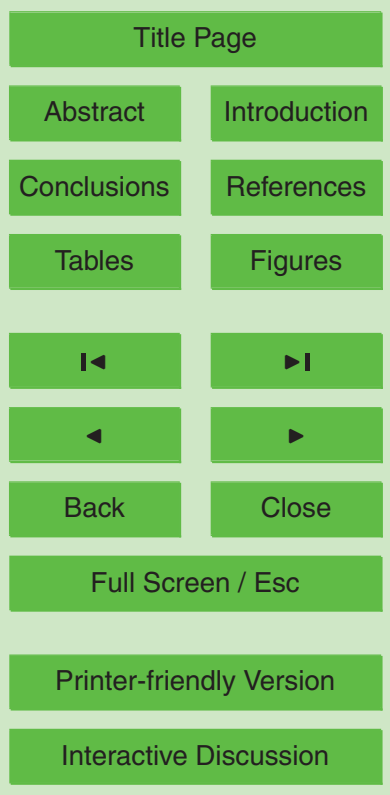

1745 
bility both of which reduce erosion potential. This expected positive relation of forest land cover as measured by Public ownership (Public.Stb) on Total Richness however was not observed. This negative relation may be due to increased human usage via harvesting of fish and decapods, representing R/S connectivity from increased human 5 access, but unrelated to sediment and water process alteration from roads. Both Total Richness and Fish Richness have negative relations with forest land cover variables Public.Stb and RipFor Patch while Decapod Richness has a positive relation RipForPatch and a negative relation with Public.Stb.

\subsection{Geomorphology models}

10 Grain Size and Channel Width are strongly influenced by the variables used in modeling having $R^{2}$ values ranging from $0.72-0.86$. Conversely, the Channel Depth and Pool Volume models have reduced $R^{2}$ values ranging from $0.22-0.52$. The Grain Size response variable is the only geomorphology variable which we have expected relations relative to $\mathrm{R} / \mathrm{S}$ connectivity from alteration to sediment and stream flow processes, thus this will be the only model discussed in detail.

For the Grain Size response, Public ownership (Public.Stb) is positively related. Public lands in NE Puerto Rico are largely forested and are expected to have reduced RSNCP. Having reduced RSNCP would be expected to yield increased median grain size because of reduced erosion. These public lands at higher elevations also coincide

with head water streams. Headwater streams have been shown to have larger average grain size relative to lower elevation, higher order streams (Pike and Scatena, personal communication). Both these factors might explain the observed positive relation with public ownership.

The positive relationship of Aspect proportion north (N.Buf) with Grain Size is diffi25 cult to interpret. The N.Buf variable might be measuring moisture received. Research performed by Torres-Sanchez (1995) found greater landslide occurrence on northeastern and east facing slopes where prevailing winds yield higher moisture levels. In the with $X$ \& $Y$ model, Extrusive geology has a negative coefficient at the Stream buffer

HESSD

$5,1731-1763,2008$

\section{Road and stream network connectivity and potentail}

K. R. Sherrill et al.

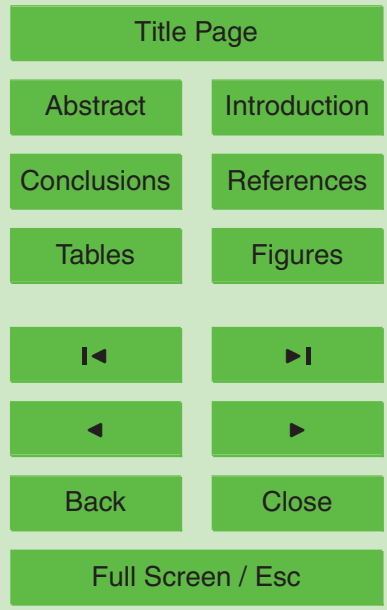

Printer-friendly Version

Interactive Discussion 
scale (Ext.Stb) with Grain Size. Increased levels of erosion resistant extrusive geology in these models are related to smaller grain size. Greater proportion small grain size might imply greater erosion and thus increased R/S connectivity in areas with increased extrusive geology, which is opposite of the expected relation with extrusive 5 geology.

Overall the Geomorphology response models have some general trends. All response models have at least one explanatory road characteristic variable. All responses are negatively related with extrusive geology (Ext.Stb) and number of river road crossings (RRCross.Buf), and positively related with Public ownership (Pub10 lic.Stb). The Extrusive geology and Public ownership relations in the geomorphology models are opposite in relation to those observed in the biota models. Due to the unknown relationship between the geomorphology response variables and R/S connectivity from alteration to sediment and water flow processes, the exploratory interpretation of the geomorphology regression models is severely limited.

\subsection{With $X$ \& $Y$ models}

Better model fit in the with $X \& Y$ models, as measured by increased $R^{2}$ and lower AIC (Table 8), is due to spatial influences on the explanatory, biota and geomorphology variables, occurring from the strong North-South topographic gradient in the study area. However, the strength and nature of these trend(s) is not understood and warrants future research. Most of the increased model fit occurring from inclusion of study site spatial coordinates is not a product of measuring R/S connectivity, but rather a product of incorporating spatial trend within the environment.

\section{Conclusions}

Modeling results support the hypothesis that multi-scale GIS variables can successfully be used to model stream biota and geomorphology responses which are influenced by

HESSD

$5,1731-1763,2008$

\section{Road and stream network connectivity and potentail}

K. R. Sherrill et al.

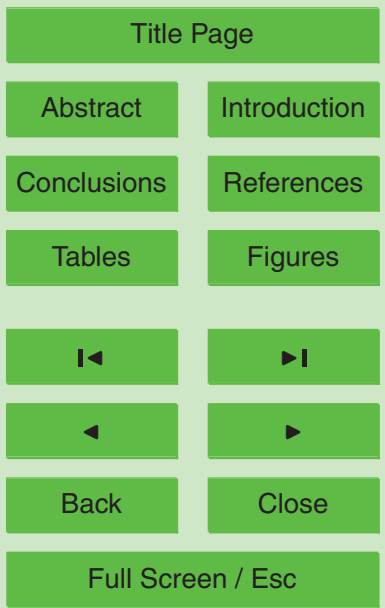

Printer-friendly Version

Interactive Discussion 
R/S connectivity. Road characteristic variables specifically are measuring the potential for road perturbation to occur in the environment, while environmental variables are measuring inherent differences in the combinations of natural situations and their potential or resistance to erosion processes. Many environmental variables, such as land 5 cover and underlying geology, have strong influences on stream erosion and hydrologic processes in the absence of roads. When land cover and geology types prone to erosion also occur in conjunction with the presence of roads, alteration of erosion and stream flow processes will be amplified.

This study explores erosion and water flow R/S connectivity and RSNCP, which is 10 only one component of the complex interactions between road and streams (i.e. R/S connectivity). Using an analysis methodology the study indirectly evaluated erosion and water flow R/S connectivity and RSNCP within the study area by modeling stream biota and geomorphology stream habitat variables, using environmental and road characteristic explanatory variables. Utilization of R/S connectivity concepts in future research will facilitate increased understanding of environmental effects resulting from interactions between road and stream networks.

Acknowledgements. The stream biota and geomorphology data used in this analysis were collected by collaborators working on the Interactions of Overlapping River and Road networks in a Changing Landscape Biocomplexity project \# DEB-0308414. We would also like to thank the International Institute of Tropical Forestry and the Luquillo Experimental Forest for use of their geospatial road and stream network data. Lastly we also would like to thank Michael Lefsky and Todd Crowl for review and comments of drafts.

\section{References}

Allan, D. J.: Stream Ecology Structure and function of running waters, Chapman and Hall, 1995.

Clark, W. and Karr, J. R.: Effect of highways on red-winged blackbird and horned lark populations, Wilson Bull. 91, 143-145, 1979.

\section{HESSD}

$5,1731-1763,2008$

\section{Road and stream network connectivity and potentail}

K. R. Sherrill et al.

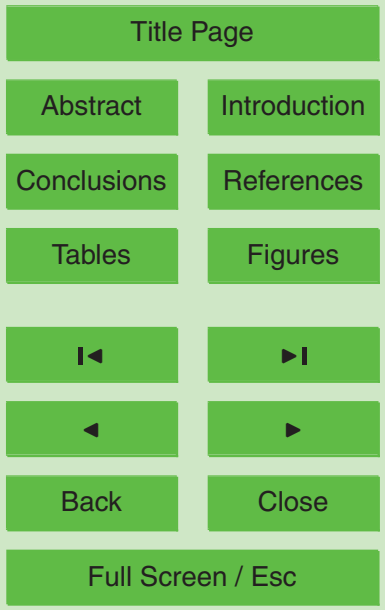

Printer-friendly Version

Interactive Discussion 
Cornish, P. M.: The effects of roading, harvesting and forest regeneration on streamwater turbidity levels in moist eucalypt forest, Forest Ecol Manag. 152, 293-312, 2001.

Covich, A. P. and McDowell, W. H.: The Stream Community. Pages 433-461, in: Food Web of a Tropical Rain Forest, edited by: Reagan, D. P and Waide, R. B., University of Chicago Press, Chicago and London., 1996.

Croke, J., Mockler, S., Fogarty, P., and Takken, I.: Sediment concentration changes in runoff pathways from a forest road network and the resultant spatial pattern of catchment connectivity, Geomorphology, 68, 257-268, 2005.

ESRI Environmental Systems Research Institute. ArcView 3.3, ArcGIS 9.1, Arclnfo 9.1 hydrological analysis and ArcToolbox proximity buffer tool.

Forman, R. T.: Land Mosaics The Ecology of Landscapes and Regions, Cambridge University Press., 1995.

Forman, R. T.: Estimate of the Area Affected Ecologically by the Road System in the United States, Conserv Biol. 14, 31-35, 2000.

Forman, R. T. and Alexander, L.: Roads and Their Major Ecological Effects.Annu Rev Ecol Syst., 29, 207-231, 1998.

Forman, R. T., Reineking, B., and Hersperger, A.: Road Traffic and Nearby Grassland Bird Patterns in a Suburbanizing Landscape, Environ Manage., 29, 782-800, 2002.

Forman, R. T., Sperling, D., Bissonette, J., Clevenger, A., Cutshall, C., Dale, V., Fahrig, L., France, R., Goldman, C., Heanue, K., Jones, J., Swanson, F., Turrentine, T., and Winter, T.: Road Ecology: science and solutions, Island Press: Washington, Covelo, London, 2003.

Foster, D. R., Fluet, M., and Boose, E. R.: Human or Natural Disturbance: Landscape-Scale Dynamics of the Tropical Forest of Puerto Rico, Ecol Appl., 9, 555-572, 1999.

Furniss, M., Roelofs, T., and Yee, C.: Road Construction and Maintenance. In: W. Meehan 25 (Editor), Influences of Forest and Rangeland management on Salmonid Fishes and Their Habitats, American Fisheries Society Special Publication., 19, 297-323, 1991.

Furnival, G. and Wilson, R.: Regressions by Leaps and Bounds, Technometrics, 16, 499-511, 1974.

Gergel, S., Turner, M. G., Miller, J. R, Melack, J. M., and Stanley, E. H.: Landscape indicators of human impacts to riverine systems, Aquat. Sci., 64, 118-128, 2002.

Gibson, J. R., Haedrich, R. L., and Wernerheim, M. C.: Loss of Fish Habitat as a Consequence of Inappropriately Constructed Stream Crossings, Fisheries, 30, 10-17, 2005.

Guariguata, M.: Landslide Disturbance and Forest Regeneration in the Upper Luquillo Moun-

HESSD

$5,1731-1763,2008$

\section{Road and stream network connectivity and potentail}

K. R. Sherrill et al.

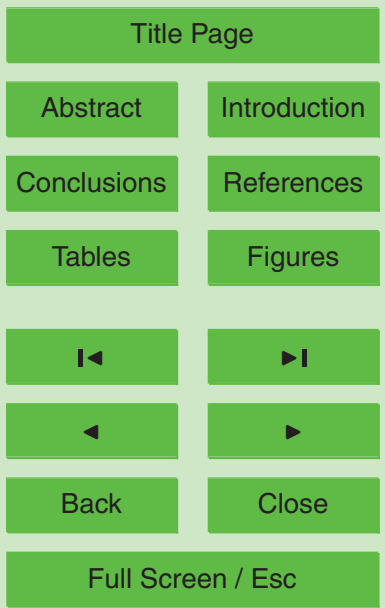

Printer-friendly Version

Interactive Discussion 
tains of Puerto Rico, J Ecol. 78, 814-832, 1990.

Grau, H. R., Aide, T. M., Zimmerman, J. K., Thomlinson, J. R., Helmer, E., and Zou, X.: The Ecological Consequences of Socioeconomic and Land-Use Changes in Postagriculture Puerto Rico, BioScience, 53, 1159-1168, 2003.

5 Helmer, E.: Forest conservation and land development in Puerto Rico, Landscape Ecol., 19, 29-40, 2004.

Heartsill-Scalley, T. and Aide, T. M.: Riparian vegetation and stream condition in a tropical agriculture-secondary forest mosaic, Ecol Appl., 13, 225-234, 2003.

Isebrands, L. G. and Crow, T.: Introduction to uses and interpretation of principal component analysis in forest biology, USDA Forest Service General Technical Report NC-17, 1975.

Jeffers, J.: Two Case Studies in the Application of Principal Component Analysis, Appl. Stat.-J. Roy. St. C., 16, 225-236, 1967.

Jones, J. A. and Grant, G. E.: Peak flow responses to clear-cutting and roads in small and large basins, western Cascades, Oregon, Water Resour. Res., 32, 959-974, 1996.

15 Jones, J. A., Swanson, F., Wemple, B., and Snyder, K.: Effects of roads on Hydrology, geomorphology, and disturbance patches in stream networks, Conserv Biol., 14, 76-85, 2000.

Kellum, B.: Analysis and Modeling of Acid Neutralizing Capacity in the Mid-Atlantic Highlands Area. Masters Project, Department of Statistics, Colorado State University, Fort Collins, 69 pp., 2002.

20 Larsen, M. C. and Torres-Sanchez, A. J.: Geographic relations of landslide distribution and assessment of landslide hazards in the Blanco, Cibuco, and Coamo basins, Puerto Rico, US Geol. Surv. Rep., 95-4029, 1995.

Larsen, M. C. and Parks, J.: How Wide is a Road? The Association of Roads and Mass-wasting in a Forested Montane Environment, Earth Surf Proc Land, 22, 835-848, 1997.

Layman, C. A., Arrington, D. A., Langerhans, B. R., and Silliman, B. R.: Degree of Fragmentation Affects Fish Assemblage Structure in Andros Island (Bahamas) Estuaries, Caribb. J. Sci., 40, 232-244, 2004.

Lugo, A. E. and Scatena, F. N.: Ecosystem-Level Properties of the Luquillo Experimental Forest with Emphasis on the Tabonuco Forest, in: Tropical Forests, edited by: Lugo, A. E. and Lowe,

30 C., Management and Ecology, New York, Springer-Verlag, 59-108, 1995.

Lugo, A. E. and Gucinski, H.: Function, effects, and management of forest roads, Forest Ecol. Manag., 133, 249-262, 2000.

Lugo, A. E.: Can we manage tropical landscapes? an answer from the Caribbean perspective,

\section{HESSD}

5, 1731-1763, 2008

\section{Road and stream network connectivity and potentail}

K. R. Sherrill et al.

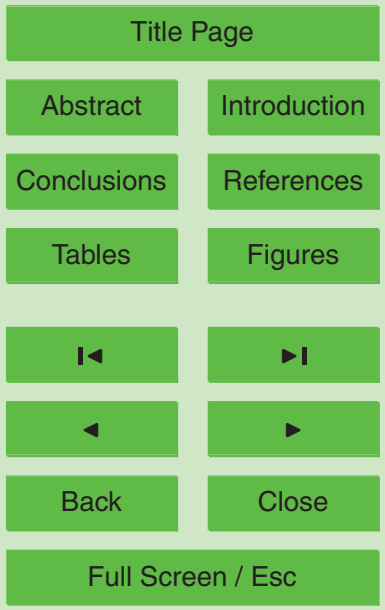

Printer-friendly Version

Interactive Discussion 
Landscape Ecol., 17, 601-615, 2002.

McDowell, W. H., and Asbury, C. E.: Export of carbon, nitrogen, and major ions from three tropical montane watersheds, Limnol. Oceanogr., 39, 111-125, 1994.

McGarigal, K., Cushman, S., and Stafford, S.: Multivariate Statistics for Wildlife and Ecology Research, Springer-Verlag New York, 2000.

Montgomery, D. R.: Road surface drainage, channel initiation, and slope instability, Water Resour. Res. 30, 1925-1932, 1994.

Mumme, R. L., Schoech, S. J., Woolfenden, G. E., and Fitzpatrick, J. W.: Life and death in the fast lane: Demographic consequences of road mortality in the Florida scrub-jay, Conserv. 10 Biol., 14, 501-12, 2000.

Neter, J., Kutner, M. H., Nachtsheim, C. J., and Wasserman, W.: Applied Linear Statistical Model's, McGraw-Hill, Boston, 4th edn., 1996.

Nichol, S.: On the interpretation of Principal Components Analysis in ecological contexts, Vegetatio, 34, 191-197, 1977.

Ramos Gonzalez, O. M.: Assessing Vegetation and Land Cover Changes in Northeastern Puerto Rico: 1978-1995, Caribb. J. Sci., 37, 95-106, 2001.

Ramos-Scharron, C. E. and MacDonald, L.: Measurement and prediction of sediment production from unpaved roads, St John, US Virgin Islands, Earth Surface Processes and Landforms, 30, 1283-1304, 2005.

20 Reed, R., Johnson-Barnard, J., and Baker, W.: Contribution of Roads to Forest Fragmentation in the Rocky Mountains, Conservation Biology, 10, 1098-1106, 1996.

Reijnen, R. and Foppen, R.: The effects of car traffic on breeding bird populations in woodland. I. Evidence of reduced habitat quality for willow warblers (Phylloscopus trochilus) breeding close to a highway, J. Appl. Ecol., 31, 85-94, 1994.

Reijnen R., Foppen, R., Ter Braak, C., and Thissen, J.: The effects of car traffic on breeding bird populations in woodland. III, Reduction of density in relation to the proximity of main roads, J. Appl. Ecol., 32, 187-202, 1995.

Reijnen, R., Foppen, R., and Meeuwsen, H.: The Effects of Traffic on the Density of Breeding Birds In Dutch Agricultural Grasslands, Biological Conservation, 75, 255-260, 1996.

30 Roth, N., Allen, J., and Erickson, D.: Landscape influences on stream biotic integrity assessed at multiple spatial scales, Landscape Ecology, 11, 41-156, 1996.

Rudel, T. K., Perez-Lugo, M., and Zichal, H.: When fields Revert to Forest: Development and Spontaneous Reforestation in Post-War Puerto Rico, Professional Geographer., 52, 386-
HESSD

$5,1731-1763,2008$

\section{Road and stream network connectivity and potentail}

K. R. Sherrill et al.

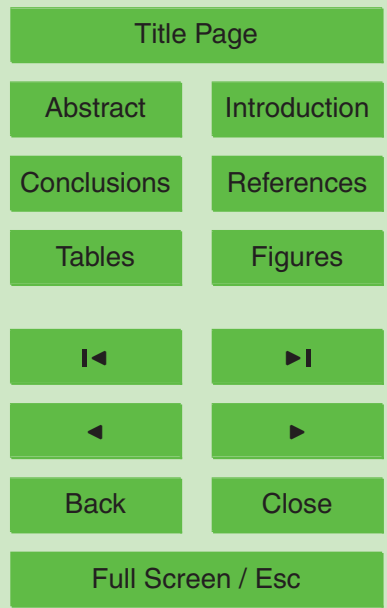

Printer-friendly Version

Interactive Discussion 
397, 2000.

Scatena, F. N. and Johnson, S. L.: Instream-Flow Analysis for the Luquillo Experimental Forest, Puerto Rico: Methods and Analysis. United States Department of Agriculture, Forest Service, International Institute of Tropical Forestry. General Technical Report IITF-GTR-11, 52001

Thomas, V. and Joy, S.: knf. Landform Index Grid. Environmental Systems Research Institute ArcView Script, 1998.

Thomlinson, J. R. and Rivera, L. Y.: Suburban growth in Luquillo, Puerto Rico: some consequences of development on natural and semi-natural systems, Landscape and Urban Planning, 49, 15-23, 2000.

Turner, M. G., Gardner, R. H., and O'Neill, R. V.: Landscape Ecology In Theory and Practice, Springer-Verlag, New York, Berlin, Heidelberg, 2001.

USDA: Forest Service International Institute of Tropical Forestry, United State Geologic Survey San Juan Puerto Rico, Geologic delineations for Puerto Rico.

Walker, L. R., Zarin, D., Fetcher, N., Myster, R., and Johnson, A.: Ecosystem Development and Plant Succession on Landslides in the Caribbean, Biotropica., 28, 566-576, 1996.

Warren, M. L. and Pardew, M.: Road Crossings as Barriers to Small-Stream Fish Movement. Transactions of the American Fisheries Society, 127, 637-644, 1998.

Wasser, S. K., Bevis, K., King, G., and Hanson, E.: Noninvasive physiological measures of disturbance in the northern spotted owl, Conservation Biology. 11, 1019-1022, 1997.

Weaver, P.: Ecosystem-Level Properties of the Luquillo Experimental Forest with Emphasis on the Tabonuco Forest, in: Tropical Forests, edited by: Lugo, A. E. and Lowe, C., Management and Ecology, New York, Springer-Verlag, 109-141, 1995.

Weller, D. E., Jordan, T. E., and Correl, D. L.: Heuristic models for material discharge from landscapes with riparian buffers, Ecological Applications, 8, 1156-1169, 1998.

Wemple, B., Jones, J., and Grant, G.: Channel Network Extension By Logging Roads in Two Basins, Western Cascades, Oregon, Water Resources Bulletin, 32, 1195-1207, 1996.

Wemple, B., Swanson, F., and Jones, J.: Forest Roads and Geomorphic Process Interactions, Cascade Range, Oregon. Earth Surface Processes and Landforms, 26, 191-204, 2001.
HESSD

$5,1731-1763,2008$

\section{Road and stream network connectivity and potentail}

K. R. Sherrill et al.

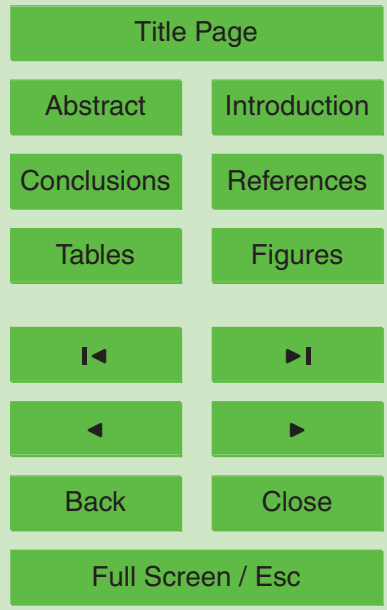

Printer-friendly Version

Interactive Discussion 


\section{HESSD}

$5,1731-1763,2008$

\section{Road and stream network connectivity and potentail}

K. R. Sherrill et al.

Table 1. Sample matrix used to select study site locations. Road size was defined as primary, secondary, tertiary, class 4 , or trail.

\begin{tabular}{llllll}
\hline \multirow{2}{*}{ Stream Size } & Road Size & & & & \\
& Primary (P) & Secondary (S) & Tertiary (T) & Class 4 (4) & Trail (Tr) \\
\hline Large (L) & LP & LS & LT & L4 & LTr \\
Medium (M) & MP & MS & MT & M4 & MTr \\
Small (S) & SP & SS & ST & S4 & STr \\
\hline
\end{tabular}

\section{Title Page}

Abstract

Introduction

Conclusions

References

Tables

Figures

14

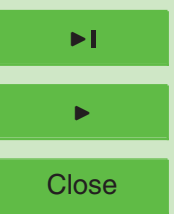

Back

Close

Full Screen / Esc

Printer-friendly Version

Interactive Discussion 
Table 2. Measured environmental variables calculated at the $250 \mathrm{~m}$ circular buffer (Buf), upstream stream $200 \mathrm{~m}$ stream buffer (Stb), and upstream contributing area (Ups) scales.

\section{HESSD}

\begin{tabular}{|c|c|}
\hline Environmental Variables & Description \\
\hline $\begin{array}{l}\text { 1. Elevation } \\
\text { Elev, (Ups, Buf, Stb) }\end{array}$ & Average Elevation Ups, Buf, and Stb (m) \\
\hline $\begin{array}{l}\text { 2. Slope } \\
\text { Slope, (Ups, Buf, Stb) }\end{array}$ & Average Slope Ups, Buf, Stb (Deg) \\
\hline $\begin{array}{l}\text { 3. Aspect } \\
\text { NE, (Ups, Buf, Stb) } \\
\text { E, (Ups, Buf, Stb) } \\
\text { SE, (Ups, Buf, Stb) } \\
\text { S, (Ups, Buf, Stb) } \\
\text { SW, (Ups, Buf, Stb) } \\
\text { W, (Ups, Buf, Stb) } \\
\text { NW, (Ups, Buf, Stb) } \\
\text { N, (Ups,Buf,Stb) }\end{array}$ & $\begin{array}{l}\text { Aspect Proportion Ups, Buf and Stb Northeast (22.6-67.5) (Deg) } \\
\text { Aspect Proportion Ups, Buf and Stb East (67.6 -112.5) (Deg) } \\
\text { Aspect Proportion Ups, Buf and Stb Southeast (112.6-157.5) (Deg) } \\
\text { Aspect Proportion Ups, Buf and Stb South (157.6-202.5) (Deg) } \\
\text { Aspect Proportion Ups, Buf and Stb Southwest (202.6-247.5) (Deg) } \\
\text { Aspect Proportion Ups, Buf and Stb West (247.6-292.5) (Deg) } \\
\text { Aspect Proportion Ups, Buf and Stb Northwest (292.6-337.5) (Deg) } \\
\text { Aspect Proportion Ups, Buf and Stb North (337.6-22.5) (Deg) }\end{array}$ \\
\hline $\begin{array}{l}\text { 4. Precipitation } \\
\text { Precip, (Ups, Buf, Stb) }\end{array}$ & Average Precipitation Ups, Buf and Stb (mm) \\
\hline $\begin{array}{l}\text { 5. Geology Proportion } \\
\text { Ext, (Ups, Buf, Stb) } \\
\text { Int, (Ups, Buf, Stb) } \\
\text { Alluv, (Ups, Buf, Stb) }\end{array}$ & $\begin{array}{l}\text { Area Extrusive Geology (Ups, Buf, Stb)/Total Area (Ups, Buf, Stb) } \\
\text { Area Intrusive Geology (Ups, Buf, Stb)/Total Area (Ups,Buf, Stb) } \\
\text { Area Alluvial Geology (Ups,Buf, Stb)/Total Area (Ups, Buf, Stb) }\end{array}$ \\
\hline $\begin{array}{l}\text { 6. Land cover Proportion } \\
\text { Agri, (Ups, Buf, Stb) } \\
\text { Urban, (Ups, Buf, Stb) } \\
\text { Forest, (Ups, Buf, Stb) }\end{array}$ & $\begin{array}{l}\text { Area Agriculture Land cover (Ups, Buf, Stb)/Total Area (Ups, Buf, Stb) } \\
\text { Area Urban Land cover (Ups, Buf, Stb)/Total Area (Ups, Buf, Stb) } \\
\text { Area Forest Land cover (Ups, Buf, Stb)/Total Area (Ups, Buf, Stb) }\end{array}$ \\
\hline $\begin{array}{l}\text { 7. Ownership Proportion } \\
\text { Public, (Ups, Buf, Stb) } \\
\text { Private, (Ups, Buf, Stb) }\end{array}$ & $\begin{array}{l}\text { Area Public Ownership (Ups, Stb, Buf)/Total Area (Ups, Stb, Buf) } \\
\text { Area Private Ownership (Ups, Stb, Buf)/Total Area (Ups, Stb, Buf) }\end{array}$ \\
\hline $\begin{array}{l}\text { 8. Riparian Land cover Proportion * } \\
\text { RipAgri, (Ups, Buf) } \\
\text { RipUrb, (Ups, Buf) } \\
\text { RipFor, (Ups, Buf) }\end{array}$ & $\begin{array}{l}\text { Area Riparian Land cover Agriculture (Ups, Buf)/Total Riparian Area (Ups, Buf) } \\
\text { Area Riparian Urban Land cover (Ups, Buf)/Total Riparian Area (Ups, Buf) } \\
\text { Area Riparian Forest Land cover (Ups, Buf)/Total Riparian Area (Ups, Buf) }\end{array}$ \\
\hline $\begin{array}{l}\text { 9. Riparian Average Patch Size* } \\
\text { RipAgriPatch } \\
\text { RipUrbPatch } \\
\text { RipForPatch }\end{array}$ & $\begin{array}{l}\text { Average Riparian Vegetation Agriculture Patch Size Ups }(\mathrm{m}) / \text { Total Riparian Area Ups } \\
\text { Average Riparian Vegetation Urban Patch Size Ups (m)/Total Riparian Area Ups } \\
\text { Average Riparian Vegetation Forest Patch Size Ups }(\mathrm{m}) / \text { Total Riparian Area Ups }\end{array}$ \\
\hline
\end{tabular}

$5,1731-1763,2008$

\section{Road and stream network connectivity and potentail}

K. R. Sherrill et al.

Title Page

Abstract

Introduction

Conclusions

References

Tables

Figures

14

I

4

Back

Close

\section{Full Screen / Esc}

Printer-friendly Version

Interactive Discussion 


\section{HESSD}

$5,1731-1763,2008$

\section{Road and stream network connectivity and potentail}

K. R. Sherrill et al.

Table 3. Road and environmental variables relationships with increased and decreased R/S connectivity related to sediment and water processes.

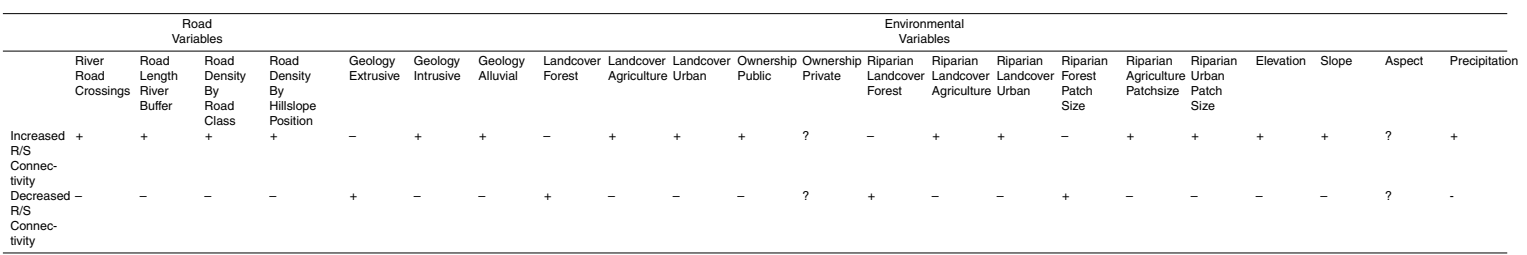

\section{Title Page}

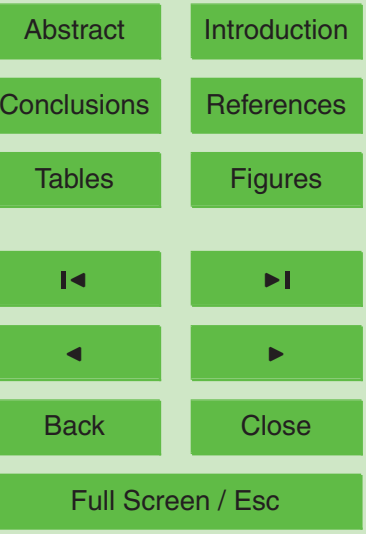

Printer-friendly Version

Interactive Discussion 
Table 4. Measured road characteristic variables calculated at the $250 \mathrm{~m}$ circular buffer (Buf), upstream stream 200 meter stream buffer (Stb), and upstream contributing area (Ups) scales.

\begin{tabular}{ll}
\hline Road Characteristics & Description \\
\hline & 1. River Road Crossings \\
\hline RRCross (Buf, Ups) & $\begin{array}{l}\text { Number of River Road Crossings (Buf and Ups) } \\
\text { Scale }\end{array}$ \\
\hline \multicolumn{1}{c}{ 2. Road Length in River Buffer 200 (m) per side } \\
\hline RdBufRiv.Buf & Length Road (m) at Buf Scale in River Buffer \\
RdDen.Stb & Length Road ( $\mathrm{km})$ at Stb Scale/Area (sq km) Stb \\
RdBufRivDen.Ups & Length Road (km) Ups in River Buffer/Area (sq km) \\
& Ups \\
\hline
\end{tabular}

3. Road Density by Class

PriDen, (Ups, Buf, Stb) SecDen (Ups, Buf, Stb)

TertDen (Ups, Buf, Stb) C4Den, (Ups, Buf, Stb) RdDen, (Ups, Buf, Stb)

Road Density Primary Roads (Ups, Buf, Stb) Scales Road Density Secondary Roads (Ups, Buf, Stb) Scales

Road Density Tertiary Roads (Ups, Buf, Stb) Scales Road Density Class 4 Roads (Ups, Buf, Stb) Scales Road Density (km) all Roads (Ups, Buf, Stb) Scales

4. Hillslope Location Road Density

RidgeDen, (Ups, Buf, Stb) Ridge Hillslope Road Density (Ups, Buf, Stb) Scales FlatDLen, (Ups, Buf, Stb) Flat Hillslope Road Density (Ups, Buf, Stb) Scales ValleyDen, (Ups, Buf, Stb) Valley Hillslope Road Density (Ups, Buf, Stb) Scales

\section{HESSD}

$5,1731-1763,2008$

\section{Road and stream network connectivity and potentail}

K. R. Sherrill et al.

\section{Title Page}

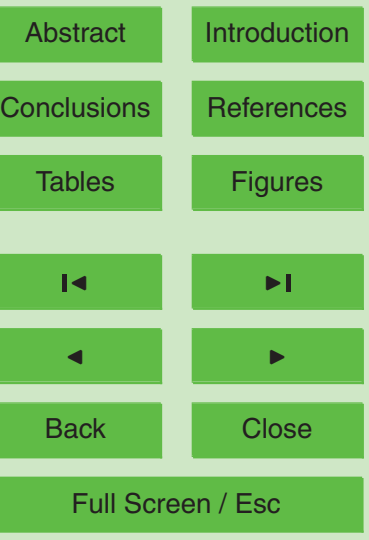

Printer-friendly Version

Interactive Discussion 
Table 5. Significant Environmental and Road Characteristic GIS variables retained after variable reduction, and used in regression modeling at each scale of study.

\begin{tabular}{|c|c|}
\hline \multicolumn{2}{|r|}{ Significant Loadings After PCA } \\
\hline Scale All & Description \\
\hline Ext.Stb* & Area Extrusive Stb/Total Area Stb \\
\hline RipForPatch* & Average Riparian Vegetation Forest Patch Size $(\mathrm{m}) /$ Total Riparian Area Ups \\
\hline E.Ups* & Aspect Proportion Ups East $(67.5-112.5)(\mathrm{Deg})$ \\
\hline N.Buf* & Aspect Proportion Buf North (337.5 -22.5) (Deg) \\
\hline Public.Stb* & Area Public Ownership Stb/Total Area Stb \\
\hline Int.Buf* & Area Intrusive Buf/Total Area Buf \\
\hline PriDen.Ups & Road Density Primary Roads Ups Scale \\
\hline RRCross.Buf & Number of River Road Crossings Buf Scale \\
\hline TertDen.Buf & Road Density Tertiary Roads Buf Scale \\
\hline C4Den.Ups & Road Density Class 4 Roads Buf Scale \\
\hline RdBufRiv.Buf & Length Road $(\mathrm{m})$ at Buf Scale in River Buffer \\
\hline SecDen.Buf & Road Density Secondary Roads Buf Scale \\
\hline \multicolumn{2}{|l|}{ Scale Ups } \\
\hline Slope.Ups* & Average Slope Ups (Deg) \\
\hline Ext.Ups* & Area Extrusive Geology Ups/Total Area Ups \\
\hline N.Ups ${ }^{*}$ & Aspect Proportion Ups North (337.5-360) (Deg) \\
\hline NE.Ups* & Aspect Proportion Ups Northeast (22.5-67.5) (Deg) \\
\hline Urban.Ups* & Area Urban Land cover Ups/Total Area Ups \\
\hline PriDen.Ups & Primary Road Length (km) Ups/ Area (sq km) Ups \\
\hline C4Den.Ups & Road Density Class 4 Roads Ups Scale \\
\hline \multicolumn{2}{|l|}{ Scale Stb } \\
\hline N.Stb* & Aspect Proportion Stb North (337.5-360) (Deg) \\
\hline C4Den.Stb & Road Density Class 4 Roads Stb Scale \\
\hline RidgeDen.Stb & Ridge Hillslope Road Density Stb Scale \\
\hline ValleyDen.Stb & Valley Hillslope Road Density Stb Scale \\
\hline Public.Stb & Area Public Ownership Stb/Total Area Stb \\
\hline \multicolumn{2}{|l|}{ Scale Buf } \\
\hline SE.Buf* & Aspect Proportion Buf Southeast (112.5-157.5) (Deg) \\
\hline E.Buf* & Aspect Proportion Buf East (67.5 -112.5) (Deg) \\
\hline N.Buf* & Aspect Proportion Buf North (337.5-360) (Deg) \\
\hline Int.Buf* & Area Intrusive Buf/Total Area Buf \\
\hline Agri.Buf* & Area Agriculture Land cover Buf/Total Area Buf \\
\hline C4Den.Buf & Road Density Class 4 Roads Buf Scale \\
\hline TertDen.Buf & Road Density Tertiary Roads Buf Scale \\
\hline SecDen.Buf & Road Density Secondary Roads Buf Scale \\
\hline RidgeDen.Buf & Ridge Hillslope Road Density Buf Scale \\
\hline
\end{tabular}

HESSD

$5,1731-1763,2008$

\section{Road and stream network connectivity and potentail}

K. R. Sherrill et al.

Title Page

Abstract

Introduction

Conclusions

References

Tables

Figures

14

$>$ I

4

Back

Close

Full Screen / Esc

Printer-friendly Version

Interactive Discussion 
Table 6. Best biota regression models across the scales of study with the highest $R^{2}$ and lowest AIC. Model covariates and coefficients for the dependent response variables. Total Richness is the combined (added) Decapod and Fish Richness, Decapod Richness (shrimp and crab species), Fish Richness (fish and eel species). With X \& Y models included either X, Y or both $X$ and $Y$ spatial covariates ( $X$ and $Y$ study site coordinates) in the regression model.

\begin{tabular}{|c|c|c|c|}
\hline \multicolumn{2}{|c|}{ Without $X \& Y$} & \multicolumn{2}{|c|}{ With $X \& Y$} \\
\hline \multicolumn{2}{|c|}{ Total Richness All Scale } & \multicolumn{2}{|c|}{ Total Richness All Scale } \\
\hline Covariates & Coefficients & Covariates & Coefficients \\
\hline (Intercept) & $10.33^{* *}$ & (Intercept) & $72.01^{* *}$ \\
\hline RdBufRiv.Buf & $-0.0019^{*}$ & RdBufRiv.Buf & $-0.0025^{*}$ \\
\hline Ext.Stb & $4.12_{\mathrm{NS}}$ & TertDen.Buf & $1.68_{\mathrm{NS}}$ \\
\hline Public.Stb & $-4.76^{*}$ & Ext.Stb & $4.88 \mathrm{NS}$ \\
\hline Int.Buf & $-8.21^{*}$ & Public.Stb & $-5.86^{* *}$ \\
\hline East.Ups & $-4.98_{N S}$ & $\begin{array}{l}\text { Int.Buf } \\
X\end{array}$ & $\begin{array}{l}-8.56^{*} \\
-0.003^{*}\end{array}$ \\
\hline AIC & 100.89 & $\mathrm{AIC}$ & 97.44 \\
\hline$R^{2}$ & 0.51 & $R^{2}$ & 0.60 \\
\hline \multicolumn{2}{|c|}{ Decapod Richness All Scale } & \multicolumn{2}{|c|}{ Decapod Richness All Scale } \\
\hline (Intercept) & $1.04_{\mathrm{NS}}$ & Intercept & $131.88^{* * *}$ \\
\hline RdBufRiv.Buf & $-0.0024^{*}$ & Ext.Stb & $12.10^{* * *}$ \\
\hline Ext.Stb & $5.79^{*}$ & Public.Stb & $-7.85^{* *}$ \\
\hline Public.Stb & $-3.76_{N S}$ & $\mathrm{X}$ & $-0.0004^{* *}$ \\
\hline RipForPatch & $3.82^{* *}$ & $\mathrm{Y}$ & $-0.0009^{* * *}$ \\
\hline AIC & 97.10 & $\mathrm{AIC}$ & 93.06 \\
\hline$R^{2}$ & 0.72 & $R^{2}$ & 0.74 \\
\hline \multicolumn{2}{|c|}{ Fish Richness Buf Scale } & \multicolumn{2}{|c|}{ Fish Richness All Scale } \\
\hline (Intercept) & $1.38^{* *}$ & (Intercept) & -18.67 NS \\
\hline Agri.Buf & $4.64^{* * *}$ & RipForPatch & $-1.88_{N S}$ \\
\hline TertDen.Buf & $1.61_{\mathrm{NS}}$ & $\begin{array}{l}\text { Int.Buf } \\
Y\end{array}$ & $\begin{array}{l}-7.17^{*} \\
0.0004^{*}\end{array}$ \\
\hline AIC & 90.84 & $\mathrm{AIC}$ & 92.21 \\
\hline$R^{2}$ & 0.53 & $R^{2}$ & 0.55 \\
\hline
\end{tabular}

\section{HESSD}

$5,1731-1763,2008$

\section{Road and stream network connectivity and potentail}

K. R. Sherrill et al.

\section{Title Page}

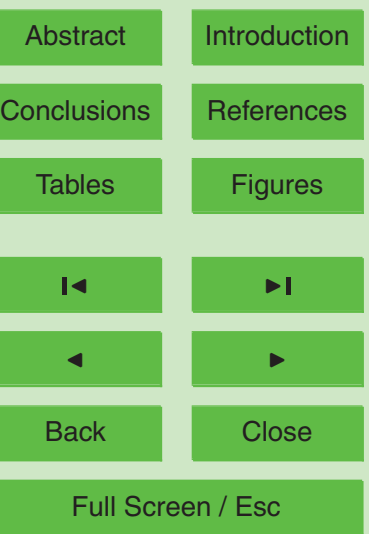

Printer-friendly Version

Interactive Discussion 
Table 7. Best geomorphology regression models across the scales of study with the highest $R^{2}$ and lowest AIC. Model covariates and coefficients, for the dependent response variables: log10 median active channel grain size, active channel maximum depth, Pool Volume, ACWidth. With $X$ \& $Y$ models included either $X, Y$ or both $X$ and $Y$ spatial covariates ( $X$ and $Y$ study site coordinates) in the regression model.

\section{HESSD}

$5,1731-1763,2008$

\section{Road and stream network connectivity and potentail}

\begin{tabular}{|c|c|c|c|}
\hline \multicolumn{2}{|c|}{ Without $X \& Y$} & \multicolumn{2}{|c|}{ With $X \& Y$} \\
\hline Covariates & Coefficients & Covariates & Coefficients \\
\hline \multicolumn{2}{|c|}{ Grain Size All scale } & \multicolumn{2}{|c|}{ Grain Size All scale } \\
\hline (Intercept) & $0.44_{\mathrm{NS}}$ & (Intercept) & $9.48^{\cdots \cdots}$ \\
\hline C4Den.Ups & $3.33^{* 5}$ & C4Den.Ups & $3.26^{\cdots \cdots}$ \\
\hline RRCross.Buf & $-0.30^{*}$ & RRCross.Buf & $-0.14_{\mathrm{NS}}$ \\
\hline SecDen.Buf & $1.07^{*}$ & SecDen.Buf & $0.88^{*}$ \\
\hline Public.Stb & $1.35^{\circ}$ & Ext.Stb & $-1.34_{\mathrm{NS}}$ \\
\hline \multirow[t]{2}{*}{ N.Buf } & $2.93 \cdots$ & N.Buf & $2.57^{* *}$ \\
\hline & & & $-0.0001 *$ \\
\hline AIC & 12.39 & AIC & 3.90 \\
\hline$R^{2}$ & 0.78 & $R^{2}$ & 0.86 \\
\hline \multicolumn{2}{|c|}{ Channel Depth All scale } & \multicolumn{2}{|c|}{ Channel Depth All scale } \\
\hline (Intercept) & $3.80^{*}$ & (Intercept) & $-36.39^{\circ}$ \\
\hline RRCross.Buf & $-0.51^{\circ}$ & RdBufRiv.Buf & $-0.61^{\circ}$ \\
\hline SecDen.Buf & $1.29_{\mathrm{NS}}$ & SecDen.Buf & $2.03^{*}$ \\
\hline \multirow[t]{4}{*}{ Ext.Stb } & $-2.19_{\mathrm{NS}}$ & Ext.Stb & $-2.80^{*}$ \\
\hline & & Public.Stb & $2.12^{*}$ \\
\hline & & $x$ & $0.0001^{\circ}$ \\
\hline & & $\mathrm{Y}$ & $0.0002^{*}$ \\
\hline AIC & 57.80 & AIC & 55.24 \\
\hline$R^{2}$ & 0.31 & $R^{2}$ & 0.51 \\
\hline \multicolumn{2}{|c|}{ Pool Volume All scale } & \multicolumn{2}{|c|}{ Pool Volume All scale } \\
\hline (Intercept) & $268.63_{\mathrm{NS}}$ & (Intercept) & $-20871.19^{*}$ \\
\hline RRCross.Buf & $-261.11^{\circ}$ & RRCross.Buf & $-227.86^{*}$ \\
\hline \multirow[t]{4}{*}{ RdBufRiv.Buf } & $0.51^{\circ}$ & Ext.Stb & $-1785.99^{* *}$ \\
\hline & & Public.Stb & $1568.23^{* *}$ \\
\hline & & & $0.06^{*}$ \\
\hline & & $\mathrm{Y}$ & $0.14 *$ \\
\hline AIC & 360.14 & AIC & 354.31 \\
\hline$R^{2}$ & 0.22 & $R^{2}$ & 0.52 \\
\hline \multicolumn{2}{|c|}{ Channel Width All scale } & \multicolumn{2}{|c|}{ Channel Width All scale } \\
\hline (Intercept) & $23.10^{\cdots *}$ & (Intercept) & $-399.16^{*}$ \\
\hline PriDen.Ups & $276.02^{* *}$ & PriDen.Ups & $178.11^{\circ}$ \\
\hline C4Den.Ups & $115.96^{\cdots *}$ & C4Den.Ups & $102.13^{\cdots *}$ \\
\hline RRCross.Buf & $-6.88^{*}$ & RRCross.Buf & $-7.17^{*}$ \\
\hline & $12.36^{*}$ & SecDen.Buf & $15.43^{*}$ \\
\hline \multirow{4}{*}{ RipForPatch } & $-9.81^{*}$ & Ext.Stb & $-28.77^{* *}$ \\
\hline & & Public.Stb & $25.2^{* *}$ \\
\hline & & $x$ & $0.0012^{\circ}$ \\
\hline & & $\mathrm{Y}$ & $0.003^{*}$ \\
\hline AIC & 166.40 & AIC & 158.73 \\
\hline$R^{2}$ & 0.72 & $R^{2}$ & 0.84 \\
\hline
\end{tabular}

1759
K. R. Sherrill et al.

\section{Title Page}

Abstract

Introduction

Conclusions

References

Tables

Figures

14

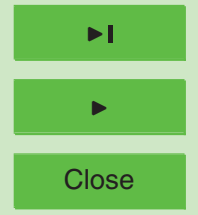

Back

Close

Full Screen / Esc

Printer-friendly Version

Interactive Discussion 


\section{HESSD}

5, 1731-1763, 2008

\section{Road and stream network connectivity and potentail}

Table 8. Differences in $R^{2}$ and $A I C$ values between the with $X \& Y$ and Without $X \& Y$ regression models (With $X \& Y-$ without $X \& Y$ ).

\begin{tabular}{llr}
\hline Modeled Response & $R^{2}$ & AIC \\
\hline Total Richness & 0.10 & -3.4 \\
Decapod & 0.02 & -4.0 \\
Fish & 0.01 & 1.4 \\
LogD50 & 0.08 & -8.5 \\
ACMaxDepth & 0.20 & -2.6 \\
Pool Volume & 0.30 & -5.8 \\
ACWidth & 0.12 & -8.0 \\
\hline
\end{tabular}

K. R. Sherrill et al.

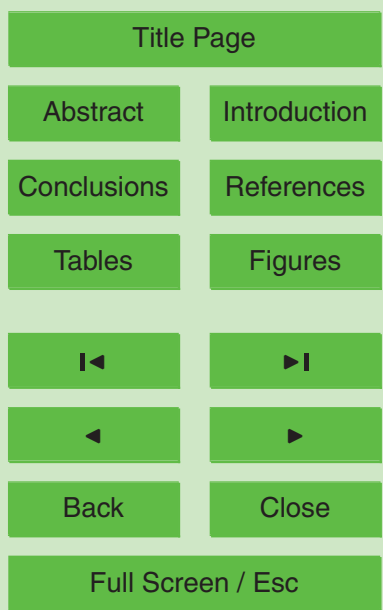

Printer-friendly Version

Interactive Discussion 
A.
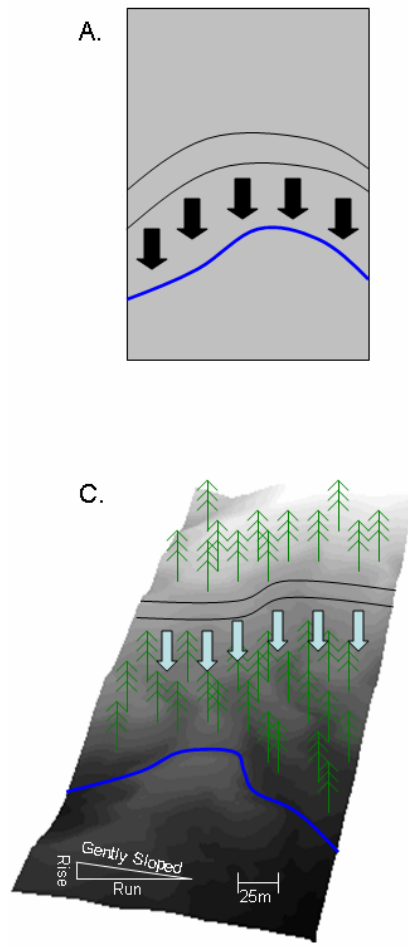

B.
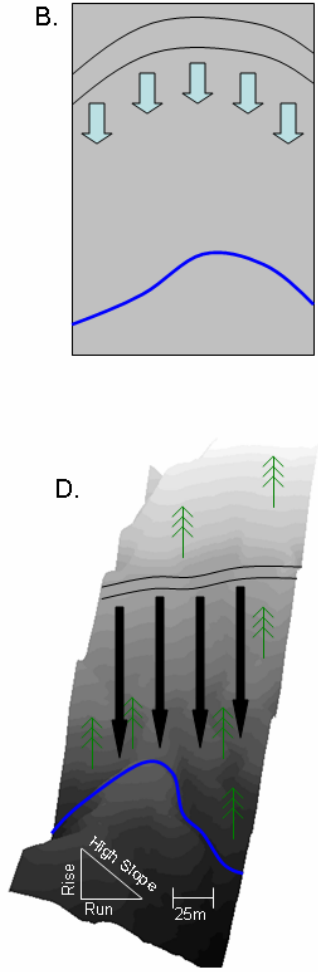

HESSD

5, 1731-1763, 2008

Road and stream network connectivity and potentail

K. R. Sherrill et al.

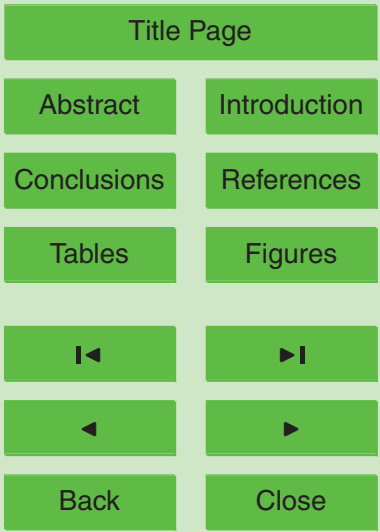

Full Screen / Esc

Printer-friendly Version

Interactive Discussion 


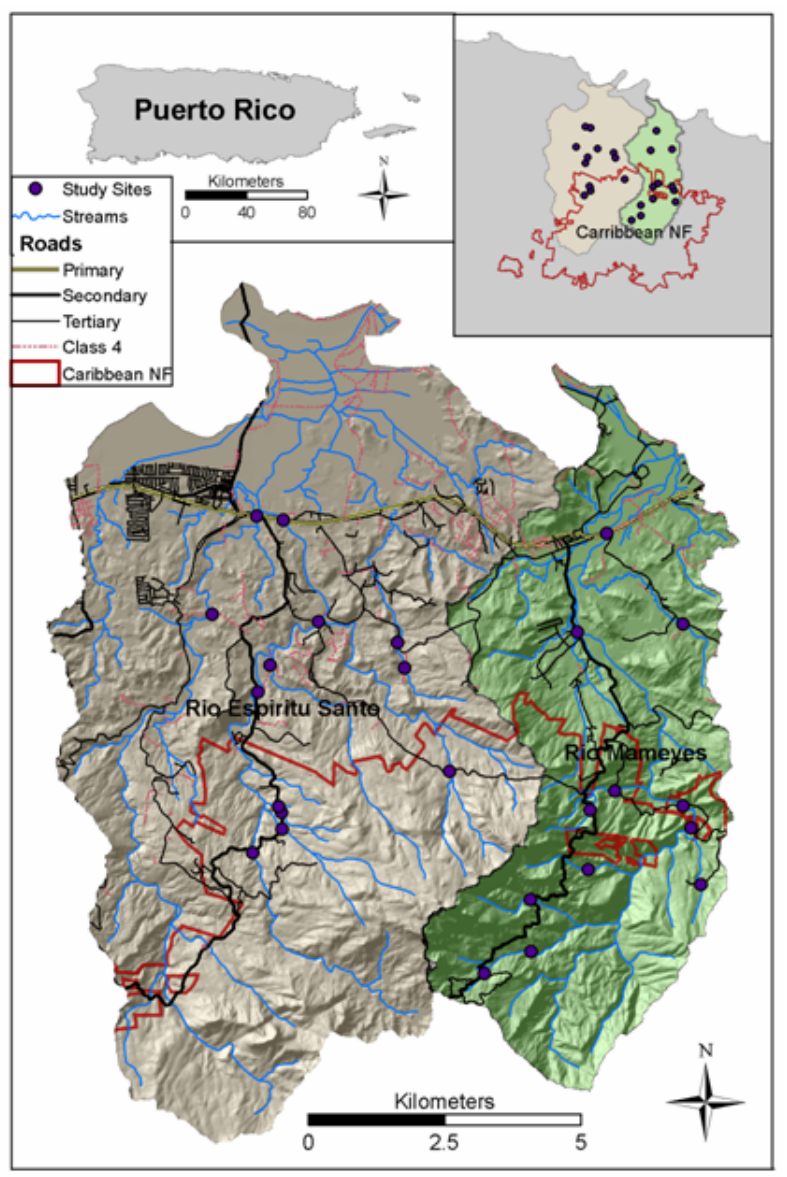

HESSD

$5,1731-1763,2008$

\section{Road and stream network connectivity and potentail}

K. R. Sherrill et al.

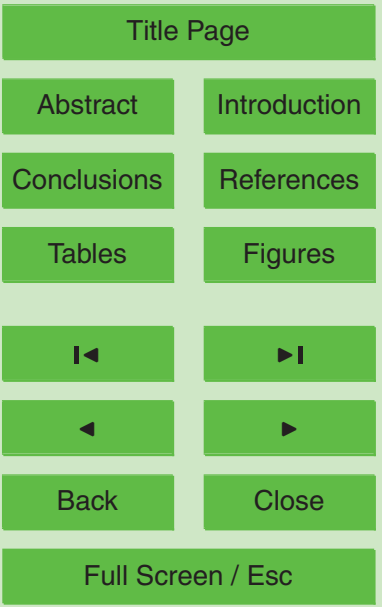

Printer-friendly Version

Interactive Discussion
Fig. 2. Study area and 25 RRC study sites in Northeastern Puerto Rico on the Rio Espiritu Santo and Rio Mameyes watersheds. 


\section{HESSD}

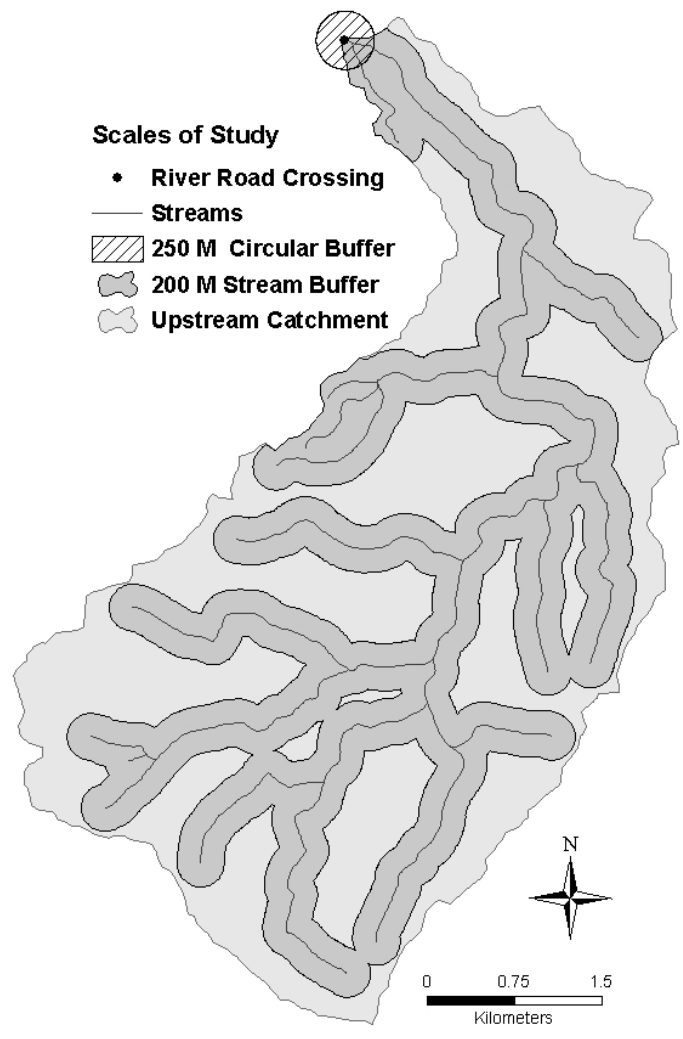

$5,1731-1763,2008$

\section{Road and stream network connectivity and potentail}

K. R. Sherrill et al.

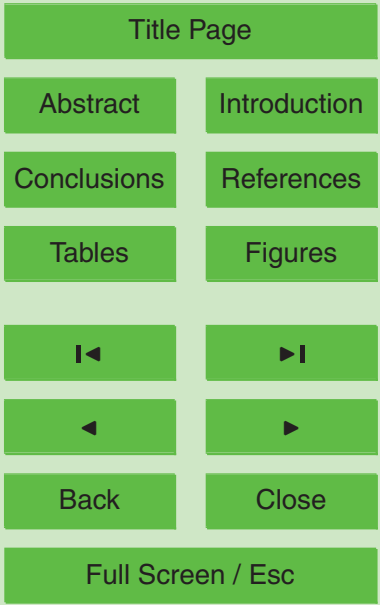

Fig. 3. Three measured hierarchical scales of study, $250 \mathrm{~m}$ circular buffer (Buf), upstream contributing areas (Ups), and a 200 m upstream stream buffer (Stb).

Printer-friendly Version

Interactive Discussion 